\title{
Research on the Scientization of University Party Building Work in the Big Data Era
}

\author{
Hao Wang
}

Shenyang Conservatory of Music, Shenyang 100081, Liaoning, China.

Abstract: The work of party building in colleges and universities is an important way and carrier to serve the development of colleges and universities and ensure that the party's policies and routes are fully implemented in colleges and universities. In the era of big data, great changes have been brought to the party building work of colleges and universities. Only by deepening the understanding of ideas and strengthening the standardized construction and application of the application of big data technology in party building work can the party building work of colleges and universities meet the needs of reform and development in the new era.

Keywords: Big Data Era; Party Building in Colleges and Universities; Scientific Construction

\section{Changes in party building work in colleges and universities in the big data era}

\subsection{Data quantification}

In the application environment of big data technology, the process and effect of various party building work in colleges and universities can be reflected in the form of data. In this way, the work development of various party organizations in colleges and universities can be measured in the form of data. In this way, party building work in colleges and universities can be more subjectively manifested, which is conducive to promoting the strict implementation of party building work measures.

\subsection{Precise prediction}

The analysis function of big data technology can comprehensively and meticulously sort and analyze the collected information and data related to party building work, and make accurate analysis and judgment based on the development direction and trend effect of the work, so as to be the leader of party building in colleges and universities. The decision-making work provided a reliable basis to effectively ensure that the party building work in colleges and universities always develops in the right direction.

\subsection{Personality construction}

The application of big data technology allows colleges and universities to establish a functional and unique party building management platform based on their actual conditions, thereby effectively attracting party members to actively participate in various party building activities organized by colleges and universities, greatly improving party building and the quality of the work allows the party building work to create more practical results.

\section{Problems in the scientific development of university party building in the era of big data}

\subsection{Institutional construction needs to be refined}

The full application of big data technology in the party building work of colleges and universities requires the updating and transformation of staff data management thinking, and they must be good at using the advantages of big data to manage various party building work. Although the application of big data can quickly and accurately complete the collection and sorting of party member information in college faculty and student groups, it provides reliable information support and sufficient convenience for the management of party building work in various party organizations in colleges and universities, 
so that party building work information can be efficient Timely disclosure has created favorable conditions for the research, deployment and implementation of party building work. However, these require a set of scientific and complete party building information data management system under the big data model to support. The current content of the management system of party building work in colleges and universities is too old, and it has not been updated and improved according to the needs of the development of the situation. This has led to the lack of clear and complete systems in the process of applying big data to specific party building work. Basis and constraints, there are many irregularities in the application of big data in many party building work. It can be seen from this that advanced technology applications must have advanced systems to provide support and guarantees, and colleges and universities still need to strengthen and improve the party building management system in the context of big data.

\subsection{Ideological construction needs to be guided}

Although the application of big data technology provides sufficient convenience for the development of party building work in colleges and universities, it makes the process and effect of party building work more rigorous in colleges and universities. However, if there is a deviation in the thinking of the staff, it will also cause serious adverse effects, and the application of big data technology in the party building work of colleges and universities will not be able to give full play to its superior value. At present, the staff responsible for party building management in some colleges and universities have not established a good sense of "big data" management, have not actively shared and disclosed party building work information, and the information communication is not smooth, and they deliberately proceed in the name of protecting data security. The blockade of information and data, or there is a deviation in the understanding of big data management, only pays attention to the collection of data information, and does not pay attention to the analysis and judgment of information, which affects the reliability of information and data quality.

If the management of party building in colleges and universities cannot establish a correct understanding in terms of consciousness, ideas, methods, etc., it will inevitably lead to a certain deviation in the application of big data. If the party building management team is unable to reverse the concept in time and focus on superficial analysis of data, it will inevitably hinder the rapid development and progress of college education in the new era. Therefore, colleges and universities must strengthen the ideological construction of the party building team to ensure that they can establish advanced ideas and concepts, and master the operation and application methods of rich big data technology, so as to provide strong support and guarantee for the improvement of the level of party building work in colleges and universities.

\section{Data responsibilities need to be clear}

The application of big data technology focuses on the value of data, but it also has the disadvantage of overemphasizing the role of data, which will make the party building work insufficiently humanized and flexible. Therefore, for the application of these "cold" data, it is necessary to add human factors to the specific development of party building work. Although the development of party building work in colleges and universities pays attention to the functional value of using data, it should not rely too much on data. It should take full account of the individualized issues among party organizations and party members, and make it from a human perspective. However, in the current practice of party building work in most colleges and universities, the division of data application management responsibilities is not clear. It is often a party building staff who undertakes multiple tasks at the same time. Due to their limited work energy, if information data appears For management problems, one person is often held accountable, or the problem is not solved. Due to the unclear responsibilities of information and data management, it is impossible to establish a fair and reasonable and benign working mechanism, which makes the enthusiasm of party building staff suffer and affect.

\section{Diversified construction methods are urgently needed}

In the past practice of party building management, the information management technology that can be applied is relatively backward, which affects the development and application effect of the value of information and data, and thus cannot provide reliable support and guarantee for the deployment and decision-making of party building. After the application of big data technology, although it has provided certain support for the progress and development of party building work, due to the insufficient level of understanding of big data technology by party building managers, the functions of party building work in colleges and universities are still too simple to promote effectively The overall level of party building work has been improved. Third, the scientific development path of university party building in the era of big data.

\subsection{Detailed system construction}

In order to ensure the standardized and orderly application of big data technology in the party building work of colleges and universities, it is necessary to strengthen the construction and improvement of the system, and provide clear norms for the application and operation of big data by party building workers. In particular, it is necessary to strictly manage the content of 
personal privacy in the information data. Strictly formulate the political life system of the party in organs, formulate several rules for political life within the party, and strictly regulate the political life system of party members through the construction of this system. Secondly, formulate democratic centralism, combine collective leadership with individual division of labor, use various methods such as speeches by party and government leaders to permeate the connotation and spirit of the system, strengthen the development of party and government courses, and do a good job in system promotion. Third, strengthen the construction of the "ritual" system, and through methods such as giving party members a "political birthday" and interacting with party members, they have an in-depth understanding of party members' ideological trends, and understand party members' opinions and suggestions on system construction, so as to solve hidden dangers under the party and government system.

\subsection{Lead correct thinking}

The development of party building work in colleges and universities should also pay attention to and guide the ideological work of party members, and understand the ideological trends of party members through diversified methods. On the one hand, we must pay attention to the application of big data technology, collect party members' data information through the development of party member networks, analyze the collected data and information, and summarize the party members' ideological trends. Secondly, pay attention to the daily work of party members, analyze and study their ideological activities through their performance in their lives and work, and analyze the hidden ideological dangers in them, and then do a good job of guiding and guiding party members' ideological work. In addition, party and government cadres should also pay attention to caring for and loving the lives of party members, and help party members with their difficulties in life, so that party members can feel the warmth of the party organization and allow party members' thinking to follow the guidance of the party organization to be correct. Direction development.

\subsection{Clear data responsibilities}

To achieve reasonable and standardized use of big data technology, it is also important to clarify the work responsibilities of data managers. It is necessary to adhere to the principle of "who uses it, who is responsible" to establish a clear and strict information and data use management responsibility mechanism, so as to effectively prevent the abuse of information and data technology. In the development of party building work in colleges and universities that apply big data technology, the personnel engaged in party building-related work are mainly responsible for the collection, sorting, transmission and preservation of information and data. Therefore, the information and data that members of the party building work team of colleges and universities must undertake the responsibility for safety management is clarified to ensure that the responsibility is assigned to the individual. Secondly, we must pay attention to keeping party members' information and materials strictly confidential, do a good job in the development of network security work, and ensure that big data technology is used in a standardized and reasonable manner by strengthening the learning and improvement of information security management technology, and achieving information security without fail.

\subsection{Diverse construction methods}

Party building departments in colleges and universities must deepen their understanding of big data technology, learn to update their own ideas, practically apply big data technology concepts to various party building tasks, and establish a unified form and rich content party building big data management platform to ensure that universities and ideological status of various party organizations and party members are quickly and accurately collected on the platform.

\section{Conclusion}

In summary, the standardized and reasonable application of big data technology can effectively promote the rapid development and progress of party building work in colleges and universities. Therefore, college party building departments must strengthen the learning and improvement of big data technology application and operation technology, innovate thinking concepts, strengthen the construction and improvement of the party building system under the application of big data technology, do a good job in the safety management of party building work information, and promote party affairs staff and ethical quality, innovative management service platform, to jointly promote the rapid improvement of the level of party building work in colleges and universities

\section{References}

1. Feng W. The organic integration of college party building culture and ideological and political education in the era of big data. Fujian Tea 2020; 42(05): 209-210.

2. Chen S. The scientific construction of the basic-level party organization in universities in the era of big data: opportunities, challenges and strategies. Journal of Chongqing Three Gorges University 2020; 36(03): 17-26. 